\title{
EFFICACY OF EICHHORNIA CRASSIPES, PISTIA STRATIOTES AND NYMPHAEA LOTUS IN THE BIOSORPTION OF NICKEL FROM REFINERY WASTEWATER
}

\author{
UGYA, A. Y. ${ }^{1,2}-$ IMAM, T. S. ${ }^{3}-$ HUA, X. ${ }^{1}-$ MA, J. ${ }^{1 *}$ \\ ${ }^{1}$ College of New Energy and Environment, Jilin University, Changchun, China \\ ${ }^{2}$ Department of Environmental Management, Kaduna State University, Kaduna State, Nigeria \\ ${ }^{3}$ Department of Biological Sciences, Bayero University Kano, Kano State, Nigeria \\ *Corresponding author \\ e-mail: jincaima@jlu.edu.cn
}

(Received 24 $4^{\text {th }}$ May 2019; accepted $28^{\text {th }}$ Aug 2019)

\begin{abstract}
The invasive nature of Eichhornia crassipes, Pistia stratiotes, and Nymphaea lotus is worrisome because they tend to dominate the economic and ecological region of the aquatic environment, hence the need for their eco-friendly utilization. This research is aimed at assessing the efficacy of Eichhornia crassipes, Pistia stratiotes and Nymphaea lotus as a low-cost absorbent for the biosorption of Nickel $\left(\mathrm{Ni}^{2+}\right)$ from refinery wastewater. Refinery wastewater was collected from the effluent point of Kaduna Refining and Petrochemical Company (KRPC). The selected macrophytes were characterized using Fourier transform infrared (FTIR) spectroscopy. Biosorption of $\mathrm{Ni}^{2+}$ from the wastewater and aqueous $\mathrm{Ni}^{2+}$ solution was performed under factors such as contact time, particle size, absorbent dosage, $\mathrm{pH}$ and $\mathrm{Ni}^{2+}$ concentration. The Langmuir equation and Freundlich isothermal were used in determining absorption equilibrium while pseudo-first and pseudo-second-order were used to determined adsorption kinetics. The result obtained shows that $\mathrm{Ni}^{2+}$ absorption by the selected macrophytes is greatly influenced by contact time, particle size, absorbent dosage, $\mathrm{pH}$ and $\mathrm{Ni}^{2+}$ concentration with high efficiency recorded in the removal of $\mathrm{Ni}^{2+}$ from refinery wastewater. Both Langmuir equation and Freundlich isothermal gives a nearly perfect fitting for adsorption of $\mathrm{Ni}^{2+}$ for all the selected macrophytes signifying favorable $\mathrm{Ni}^{2+}$ absorption. Pseudo-second-order kinetic model gives nearly perfect fitting than the pseudo secondorder kinetic model signifying that adsorption of $\mathrm{Ni}^{2+}$ by the selected macrophytes is due to the physical and chemical reaction. The selected macrophyte can be effectively utilized as low-cost biosorbents for the removal of $\mathrm{Ni}^{2+}$ from Refinery wastewater.
\end{abstract}

Keywords: Langmuir equation, adsorption kinetics, macrophytes, heavy metals, invasive species

\section{Introduction}

Aquatic macrophytes are plants that can survive in or around water bodies (Osti et al., 2018). They are classified into four major groups namely emergent macrophyte, floating leaves macrophyte, submerged macrophyte and free-floating macrophyte (Bordoloi et al., 2015; Galal and Farahat, 2015; Pulzatto et al., 2018). The ability of Eichhornia crassipes, Pistia stratiotes and Nymphaea lotus to overtop ecological and economic zones of aquatic ecosystem is alarming due to the negative impact it causes on economic yield, human health and aquatic organisms (Lamb et al., 2016). These macrophytes hindered the penetration and flow of sunlight due to their ability to extend over water bodies (Ugya, 2015; Ma et al., 2019).

The control of Eichhornia crassipes, Pistia stratiote and Nymphaea lotus is necessary because of the macrophytes to interfere with water flow and sunlight penetration which is detrimental to flora and fauna inhabiting the habitat (Ugya et al., 2019a). Different control method has been used against these plants in the past but 
recent research has focused on how to utilize the benefit associated with these plants (Lareo, 1981; Chen et al., 2012; Hanks et al., 2015).

The incessant discharge of heavy metal polluted water into the environment is worrisome due to their persistence nature and ability to accumulate in the food chain (Dudgeon et al., 2006; Lintern et al., 2016; Ugya and Imam, 2017; Liu et al., 2018). The menace associated with heavy metal pollution is endemic in developing countries where industries channel wastewater into nearby water bodies either untreated or not properly treated due to their proximity to these water bodies (Ugya et al., 2015; Desrosiers et al., 2019). The wastewater produced by oil refinery industries is rich in heavy metals particularly $\mathrm{Ni}^{2+}$ which pose serious toxicity at low-level exposure (Hughes et al., 2015; Ugya et al., 2019b). These heavy metal have been shown by many researchers to be associated with chronic and acute toxicological effects to man and detrimental to organisms such as algae, plants, micro-organisms and other vertebrate and invertebrate animals (Costa-Boeddeker et al., 2018; Wang et al., 2018; Xun et al., 2018; Ugya et al., 2019c). It is thereby paramount to treat wastewater before discharge (Zhang and Anadon, 2013; Tong and Elimelech, 2016).

A variety of techniques are available for the treatment of wastewater before discharging into water bodies, many of which have contributed in minimizing pollution resulting from chemical industries, but biosorption is gaining acceptance owing to the fact that most researchers have revealed the potentiality of some bio sorbents to effectively remediate wastewater with high heavy metal pollutants (Nahar et al., 2018; Ugya et al., 2019d). Biosorption is a remediation technology that depends on the mechanism of heavy metal accumulation by agricultural or biological adsorbents from an aqueous solution as a result of the binding site present on this bio sorbents (He and Chen, 2014; Ileri et al., 2014; Abdic et al., 2018). Eichhornia crassipes, Pistia stratiote, and Nymphaea lotus have been utilized by researchers such as in the biosorption of $\mathrm{Cd}$, $\mathrm{Pb}, \mathrm{Cr}$, etc but little or no literature exists for the biosorption of $\mathrm{Ni}^{2+}$ from refinery wastewater. This study is aimed at assessing the efficacy of Eichhornia crassipes, Pistia stratiote and Nymphaea lotus as a low-cost absorbent for the biosorption of $\mathrm{Ni}^{2+}$ from refinery wastewater.

\section{Materials and methods}

\section{Sample collection, authentication, and preparation}

Eichhornia crassipes, Pistia stratiote, and Nymphaea lotus were collected at three different abandon pond of proximity located at Kinkinau, Ungwar Ma'azu, Kaduna South Local Government, Kaduna State, Nigeria. The macrophytes were handpicked with the aid of hand gloves, identified using relevant guides (Gusain and Suthar, 2017; Hanafiah et al., 2018) and authenticated in the herbarium of the Department of Botany, Ahmadu Bello University Zaria, Kaduna State, Nigeria and Department of Plant Biology, Bayero University Kano, Kano State, Nigeria (Table 1) (Ugya et al., 2019e). The macrophytes were cut into small pieces, washed twices with borehole water and once using distilled water and were dried in sunlight for $48 \mathrm{~h}$. The macrophytes were grounded using a mechanical blender (Greenis, FGR-8840) and sieved accordingly to obtain Large $(60 \mathrm{~mm})$ and small $(30 \mathrm{~mm})$ particle sizes of Eichhornia crassipes, Pistia stratiote, and Nymphaea lotus. The macrophytes powders were stored separately in an airtight container before use. Refinery wastewater sample was collected from the effluent point of Kaduna Refining and Petrochemical Company (KRPC), which is in 
Chikun Local Government, Kaduna State, Nigeria around latitude $10^{\circ} 24^{\prime} 36.18^{\prime \prime} \mathrm{N}$ and longitude $7^{\circ} 29^{\prime} 17.37^{\prime}$ 'E. The physicochemical and heavy metal characteristic of the wastewater was determined using standard method.

Table 1. Test plants used for biosorption

\begin{tabular}{c|c|c|c}
\hline SN & Plants & Common name & Accession number \\
\hline 1 & Eichhornia crassipes & Water Hyacinth & 3268 \\
2 & Pistia stratiotes & Water Lettuce & 1977 \\
3 & Nymphaea lotus & Water lily & BUKHAN0356 \\
\hline
\end{tabular}

\section{Sorbent characterization}

The functional groups present in the treated and untreated Eichhornia crassipes, Pistia stratiote and Nymphaea lotus were determined using Fourier transform infrared (FTIR) spectroscopy (Rosales et al., 2016).

\section{Effect of particle size and contact time on $\mathrm{Ni}^{2+}$ adsorption}

The effect of contact time and particle size was determined by placing $2 \mathrm{~g}$ of Eichhornia crassipes, $0.5 \mathrm{~g}$ Pistia stratiote and $1 \mathrm{~g}$ Nymphaea lotus of two different particle sizes (30 mm (small size) and $60 \mathrm{~mm}$ (large size)) in separately in $250 \mathrm{ml}$ containing $4.5 \mathrm{mg} / \mathrm{l}$ of $\mathrm{Ni}^{2+}$. The mixture was shaken at $150 \mathrm{rpm}$ using a magnetic shaker at a constant temperature of $25^{\circ} \mathrm{C}$. Each set of flasks were agitated for 20, 30, 40, 50 and $60 \mathrm{~min}$, respectively (Fig. 1). The sample was then filtered and $\mathrm{Ni}^{2+}$ concentrations of the solution were determined using AAS techniques. Biosorption capacity was thus calculated using the mass balance formula below (Amer et al., 2015):

$$
q=\frac{w\left(c_{1}-c_{r}\right)}{m}
$$

where $q(\mathrm{mg} / \mathrm{g})$ is the adsorption capacity, $C_{l}$ and $C e$ are the initial and final concentrations $(\mathrm{mg} / \mathrm{l})$ of $\mathrm{Ni}^{2+}$, respectively, $v(\mathrm{l})$ is the volume of aqueous and $m$ is the weight (mass) of adsorbent ( $\mathrm{g}$ ).

Percentage removal was calculated using the formula:

$$
q \% \text { uptake }=\frac{\left(c_{0}-c_{2}\right)}{c_{0}} \cdot 100
$$

where $C_{0}$ and $C_{e}$ are the initial and final concentrations $(\mathrm{mg} / \mathrm{l})$ of $\mathrm{Ni}^{2+}$ ions in the sample before and after shaking, respectively.

\section{Effect of $\mathrm{Ni}^{2+}$ concentration on adsorption process}

To $250 \mathrm{~m} / \mathrm{l}$ of solution containing $10 \mathrm{mg} / 1,20 \mathrm{mg} / \mathrm{l}, 30 \mathrm{mg} / \mathrm{l}, 40 \mathrm{mg} / \mathrm{l}$, and $50 \mathrm{mg} / \mathrm{l}$ of $\mathrm{Ni}, 1 \mathrm{~g}$ of dried Eichhornia crassipes, $0.5 \mathrm{~g}$ Pistia stratiote, and $1 \mathrm{~g}$ Nymphaea lotus were added separately and the mixture was shaken at $150 \mathrm{rpm}$ using a magnetic shaker at a temperature of $25^{\circ} \mathrm{C}$ for $1 \mathrm{~h}$. The sample was then filtered and $\mathrm{Ni}^{2+}$ concentrations of the solution were measured using AAS techniques. $\mathrm{Ni}^{2+}$ percentage reduction of $\mathrm{Ni}^{2+}$ was thus calculated using Equation 2 (Kumar et al., 2018). 


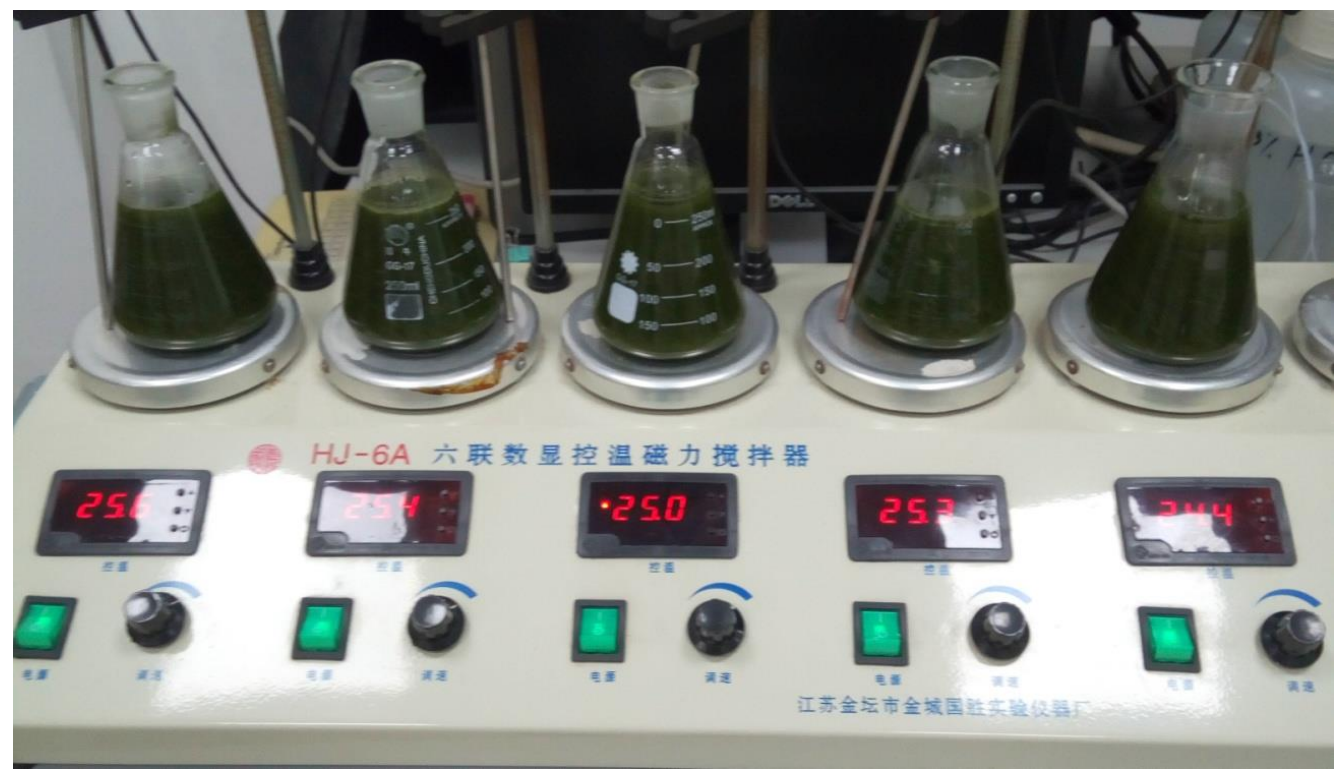

Figure 1. Experimental setup during culture

\section{Effect of pH on $\mathrm{Ni}^{2+}$ adsorption process}

The absorption ability of the macrophytes was compared at a $\mathrm{pH}$ of 2, 4, 6, 7, and 8 by placing $1 \mathrm{~g}$ of dried Eichhornia crassipes, $0.5 \mathrm{~g}$ Pistia stratiote and $1 \mathrm{~g}$ Nymphaea lotus in $250 \mathrm{ml}$ each of the solution of $\mathrm{Ni}^{2+}$ at $4.5 \mathrm{mg} / \mathrm{l}$ and shaken at $150 \mathrm{rpm}$ for $1 \mathrm{~h}$ using a magnetic stirrer at a constant temperature of $25^{\circ} \mathrm{C}$. The samples were filtered and the $\mathrm{Ni}^{2+}$ concentrations of the solution were determined using AAS technique. $\mathrm{Ni}^{2+}$ percentage removal was calculated using Equation 2 (Kumar et al., 2018). The pH of the solution was adjusted using $0.01 \mathrm{~N} \mathrm{NaOH}$ and $\mathrm{HNO}_{3}$ (Salim et al., 2016).

\section{Effect of absorbent dosage}

The effect of adsorbent dosage was studied by placing $1 \mathrm{~g}, 2 \mathrm{~g}, 3 \mathrm{~g}, 4 \mathrm{~g}$, and $5 \mathrm{~g}$ each of Eichhornia crassipes, $1 \mathrm{~g}, 2 \mathrm{~g}, 3 \mathrm{~g}, 4 \mathrm{~g}$, and $5 \mathrm{~g}$ each Nymphaea lotus and $0.2 \mathrm{~g}$, $0.4 \mathrm{~g}, 0.6 \mathrm{~g}, 0.8 \mathrm{~g}$ and $1 \mathrm{~g}$ of Pistia stratiotes where placed in to a solution $250 \mathrm{ml}$ of solution containing $4.5 \mathrm{mg} / \mathrm{l}$ of $\mathrm{Ni}^{2+}$ and shaken at $150 \mathrm{rpm}$ using a magnetic stirrer for $1 \mathrm{~h}$ at a constant temperature of $25^{\circ} \mathrm{C}$. The samples were filtered and the $\mathrm{Ni}^{2+}$ concentrations of the solution were determined using AAS technique. $\mathrm{Ni}^{2+}$ Percentage removal was calculated using Equation 2 (Kumar et al., 2018).

\section{Adsorption equilibrium study}

Adsorption equilibrium study for $\mathrm{Ni}^{2+}$ using Eichhornia crassipes, Pistia stratiote and Nymphaea lotus was performed by placing $1 \mathrm{~g}, 2 \mathrm{~g}, 3 \mathrm{~g}, 4 \mathrm{~g}$, and $5 \mathrm{~g}$ of Eichhornia crassipes, $1 \mathrm{~g}, 2 \mathrm{~g}, 3 \mathrm{~g}, 4 \mathrm{~g}$, and $5 \mathrm{~g}$ Nymphaea lotus and $0.2 \mathrm{~g}, 0.4 \mathrm{~g}, 0.6 \mathrm{~g}, 0.8 \mathrm{~g}$ and $1 \mathrm{~g}$ of Pistia stratiotes in $5 \mathrm{mg} / \mathrm{l}, 10 \mathrm{mg} / \mathrm{l}, 15 \mathrm{mg} / \mathrm{l}, 20 \mathrm{mg} / \mathrm{l}$ and $25 \mathrm{mg} / \mathrm{l} \mathrm{of} \mathrm{Ni}^{2+}$ and shake at using a magnetic stirrer at $150 \mathrm{rpm}$ for $24 \mathrm{~h}$ at a constant temperature of $25^{\circ} \mathrm{C}$. The samples were filtered and the $\mathrm{Ni}^{2+}$ concentrations of the solution were determined using AAS technique. Langmuir and Freundlich isotherm models were thus determined using Equations 3 and 5 (Manikandan et al., 2016).

Langmuir equation is represented below: 


$$
\frac{1}{q_{x}}=\frac{1}{b_{i} q_{f}} \cdot T_{e}+\frac{1}{q_{f}}
$$

The equation above was adopted from Kumar et al. (2018), where $T_{e}$ is equilibrium $\mathrm{Ni}^{2+}$ concentration in solution, $q_{f}$ is maximum $\mathrm{Ni}^{2+}$ absorbed per unit weight of Eichhornia crassipes, Pistia stratiote, and Nymphaea lotus, $b_{i}$ is affinity adsorbate. The value of $q_{f}$ and $b_{i}$ is determined from the slope and intercept. $Z_{l}$ is the separation factor and is calculated using the formula below:

$$
Z_{\mathrm{I}}=\frac{1}{1+b_{\mathrm{i}} T_{g}}
$$

where $T_{g}$ is the initial concentration of $\mathrm{Cr}^{3+}$ and $\mathrm{Pb}^{2+}$ in the solution.

Freundlich Isotherm is represented below:

$$
\log \left(q_{x}\right)=\log \left(K_{f}\right)+\frac{1}{\gamma \log T_{g}}
$$

The equation was adopted from Wang et al. (2010), where $K_{f}$ is Freundlich constant $r$ is Freundlich coefficient, and $K_{f}$ and $r$ are determined by plotting a graph of $q_{x}$ against $T$ (Wang et al., 2010).

\section{Adsorption kinetics}

Adsorption kinetics is fundamental in describing the character of an absorbent. To ascertain the mechanism involved in the adsorption of $\mathrm{Ni}^{2+}$ by Eichhornia crassipes, Pistia stratiote, and Nymphaea lotus. Pseudo first-order and the pseudo second-order reaction was used (Ho and McKay, 1998).

The pseudo first-order is represented below:

$$
\log \left(q_{\mathrm{i}}-q_{\mathrm{t}}\right)=\log \left(q_{\mathrm{i}}\right)-\frac{K_{\mathrm{i}} \mathbb{T}^{2}}{2.80 \mathrm{a}}
$$

The pseudo second order is represented below:

$$
\frac{T}{q_{t}}=\frac{1}{K_{2} q_{2}}+\frac{T}{q_{2}}
$$

\section{Data treatment}

Experiments were conducted in triplicate and data were analyzed statistically and presented as mean \pm standard deviation as represented by error bar on figures. The Residual Sum of Squares (RSS) was determined for both adsorption kinetic and isotherm models to check error in model fittings. All analysis was done using BM SPSS statistics version 23

\section{Results and discussion}

\section{Physicochemical and heavy metal characteristic of KRPC wastewater}

The result represented in Table 2 shows the heavy metal and physicochemical status of KRPC wastewater. Most of the parameters determine such as total suspended solid (TSS), electrical conductivity (EC) and hardness were within the permissible limit for 
wastewater except for total dissolve solid (TDS), alkalinity and turbidity which were above the permissible limit as such indicate pollution resulting from organic and inorganic pollutants. $\mathrm{Cu}^{2+}$ and $\mathrm{Ni}^{2+}$ were within the permissible limit whereas $\mathrm{Cd}^{2+}$ was above the permissible limit and could pose a threat to aquatic organisms. Although, it has been reported that $\mathrm{Ni}^{2+}$ is an essential element needed for different biochemical and physiological pathways in biological systems, excess amount of $\mathrm{Ni}^{2+}$ could lead to cellular and tissue damage leading to a variety of disease. The detectable amount of $\mathrm{Ni}^{2+}$ in the wastewater was within the permissible limit of wastewater by WHO but this could still pose a treat to man and other aquatic organisms because of the persistence's nature of $\mathrm{Ni}^{2+}$ and subsequent bioaccumulation in the food chain (Tchounwou et al., 2012).

Table 2. The physicochemical and heavy metal characteristic of KRPC wastewater

\begin{tabular}{c|c|c|c}
\hline SN & Parameter & Mean \pm SD & WHO limit (2004) \\
\hline 1 & pH & $7.2 \pm 0.75$ & $6-9$ \\
2 & Turbidity & $15.4 \pm 5.02$ & 5 \\
3 & EC & $65.5 \pm 13.42$ & $50-500$ \\
4 & TDS & $1219.50 \pm 680.70$ & 500 \\
5 & TSS & $8.40 \pm 6.40$ & 30 \\
6 & Alkalinity & $98.95 \pm 43.57$ & 50 \\
7 & Hardness & $30.96 \pm 17.23$ & 500 \\
8 & Nitrate & $2.07 \pm 0.50$ & - \\
9 & Chloride & $33.28 \pm 7.94$ & - \\
10 & $\mathrm{Ni}^{2+}$ & $0.54 \pm 0.08$ & 3.0 \\
11 & $\mathrm{Cd}^{2+}$ & $0.09 \pm 0.06$ & 0.003 \\
12 & $\mathrm{Cu}^{2+}$ & $1.77 \pm 0.27$ & 2.0 \\
\hline
\end{tabular}

Mean $\pm \mathrm{SD}$ are expressed in $\mathrm{mg} / \mathrm{l}$ except for $\mathrm{pH}$ (no unit)

\section{Characterization of biosorbent}

The result obtains for the surface characterization of biosorbent using FTIR spectrum analysis (Fig. 2) shows that the functional group changes occur in the profile of Eichhornia crassipes, Pistia stratiotes and Nymphaea lotus following the absorption of $\mathrm{Ni}^{2+}$. The peak at nearly $3500 \mathrm{~cm}^{-1}$ for untreated Eichhornia crassipes, Pistia stratiotes, and Nymphaea lotus represent the presence of $\mathrm{OH}^{-}$group, this $\mathrm{OH}^{-}$group has been stretched to $\mathrm{Ni}-\mathrm{OH}$ bond in treated Eichhornia crassipes, Pistia stratiotes, and Nymphaea lotus as shown in Figure 2. The peak at nearly $1500 \mathrm{~cm}^{-1}$ shows the presence of $\mathrm{CH}_{2}$ functional group in untreated Eichhornia crassipes, Pistia stratiotes and Nymphaea lotus, the stretching seen in the same peak for treated Eichhornia crassipes, Pistia stratiotes and Nymphaea lotus is attributed to the absorption of $\mathrm{Ni}^{2+}$. The peak at nearly $3000 \mathrm{~cm}^{-1}$ for untreated Eichhornia crassipes, Pistia stratiotes, and Nymphaea lotus shows the presences of $\mathrm{C}-\mathrm{H}$ functional group which stretches in the treated Eichhornia crassipes, Pistia stratiotes and Nymphaea lotus due to absorption of $\mathrm{Ni}^{2+}$ (Sujatha et al., 2013). 


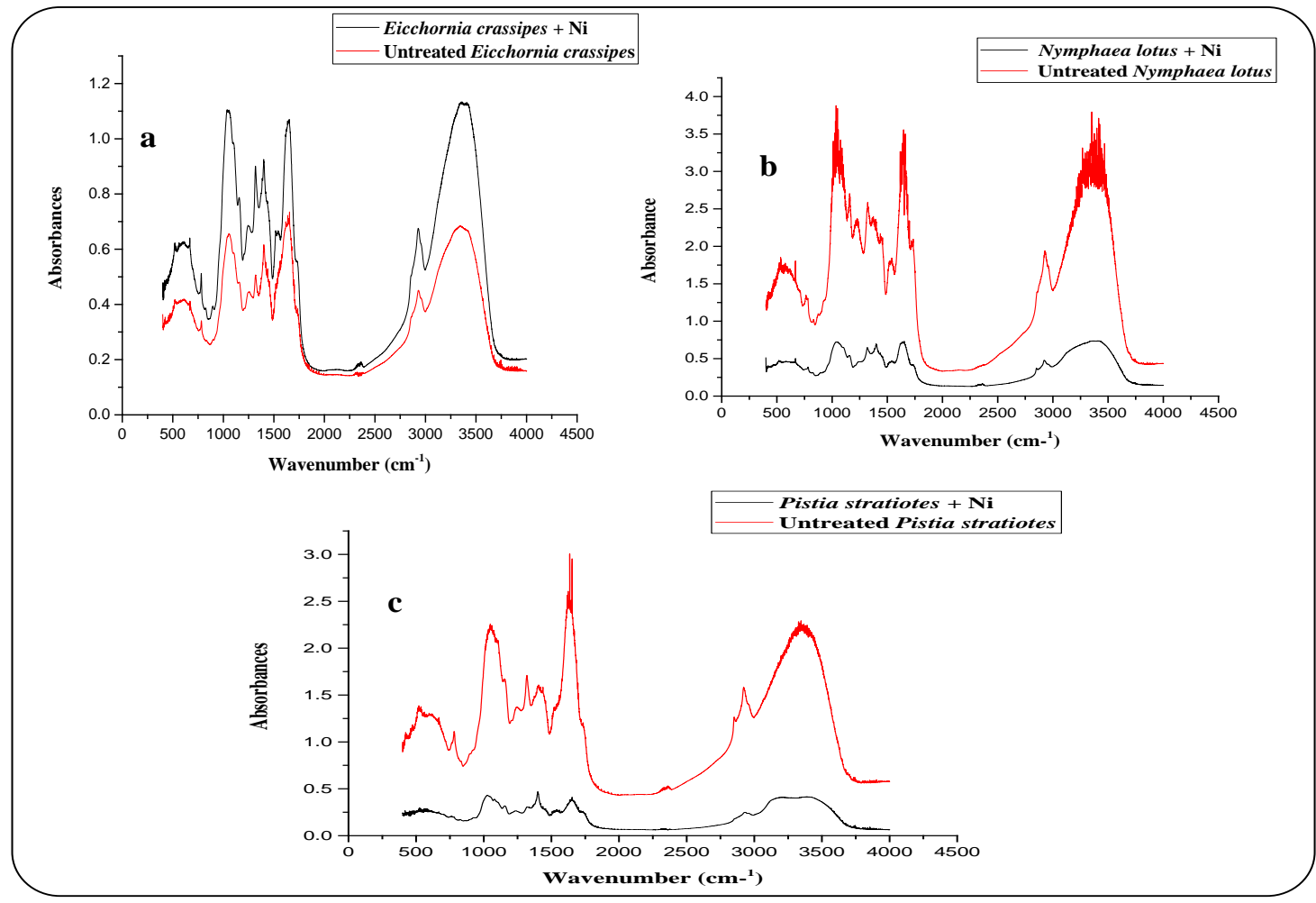

Figure 2. FTIR of (a) Eichhornia crassipes (b) Nymphaea lotus and (c) Pistia stratiotes before and after treatment

\section{Effect of $\mathrm{Ni}^{2+}$ concentration and absorbent dosage on adsorption process}

The result in Figure $3 a$ shows that $\mathrm{Ni}^{2+}$ absorption by the macrophytes is strongly influenced by the change in $\mathrm{Ni}^{2+}$ concentration because significant difference exists between the absorption of $\mathrm{Ni}^{2+}$ by Eichhornia crassipes, Pistia stratiotes and Nymphaea lotus at $\mathrm{Ni}^{2+}$ concentration of $10 \mathrm{mg} / \mathrm{l}$ if compared to $20 \mathrm{mg} / \mathrm{l}, 30 \mathrm{mg} / \mathrm{l}, 40 \mathrm{mg} / \mathrm{l}$, and $50 \mathrm{mg} / \mathrm{l}$. This enhanced absorption of $\mathrm{Ni}$ ion at a concentration of $10 \mathrm{mg} / \mathrm{l}$ by the 3 absorbents is attributed to the fact that at the concentration of $10 \mathrm{mg} / \mathrm{l}$ the 3 absorbents have available binding sites to bind $\mathrm{Ni}^{2+}$ but these binding sites become saturated as metal ion increase (Feng et al., 2011). The result in Figure $3 b$ shows that a significant difference exists in $\mathrm{Ni}^{2+}$ absorption for various dosages of Eichhornia crassipes, Pistia stratiotes, and Nymphaea lotus. These increasing trend of $\mathrm{Ni}^{2+}$ absorption with increasing dosage could be attributed to favorable $\mathrm{pH}$ of the solution and the fact that an increase in dosage of absorbent lead to increase of the maximum $\mathrm{Ni}^{2+}$ uptake due to availability of more binding site.

\section{Effect of particle size, contact time and $\mathrm{pH}$ on Ni absorption}

The result obtained shows higher reduction efficacy of $\mathrm{Ni}^{2+}$ from aqueous solution by biosorbent of larger size $(60 \mathrm{~mm})$ if compared to smaller sizes $(30 \mathrm{~mm})$ (Fig. 4). This significant differences could be attributed to the fact that the $60 \mathrm{~mm}$ biosorbent is porous as such have larger surfaces which permit increase $\mathrm{Ni}^{2+}$ absorption while $30 \mathrm{~nm}$ biosorbent is less porous as such have fewer surfaces whereas the absorption potential of a biosorbent depends on the number of surfaces of the biosorbent (Migahed et al., 
2017). The highest reduction efficacy of $\mathrm{Ni}^{2+}$ was recorded at a $\mathrm{pH}$ of 4 (Fig. 5a) this result could be attributed to the fact that the solubility of $\mathrm{Ni}$ is at $\mathrm{pH} 4$ or the binding site of Eichhornia crassipes, Pistia stratiotes and Nymphaea lotus were activated at $\mathrm{pH}$ of 4. The result obtained in (Fig. $5 b$ ) shows that $\mathrm{Ni}^{2+}$ was effectively adsorbed by Eichhornia crassipes, Pistia stratiotes, and Nymphaea lotus at all the contact time when exposed to refinery wastewater, this could be attributed to the fact that binding is available via out the period of adsorbent exposure to $\mathrm{Ni}^{2+}$. The availability of binding site via out the period of adsorbent exposure could be due to the fact that the competition of binding sites by $\mathrm{Ni}^{2+}$ is minimal even though other metals such as $\mathrm{Cd}^{2+}, \mathrm{Pb}^{2+}, \mathrm{Cr}^{3+}$, etc were presences but the concentration is too low to cause competition for binding by the coions present (Nor, 1994).

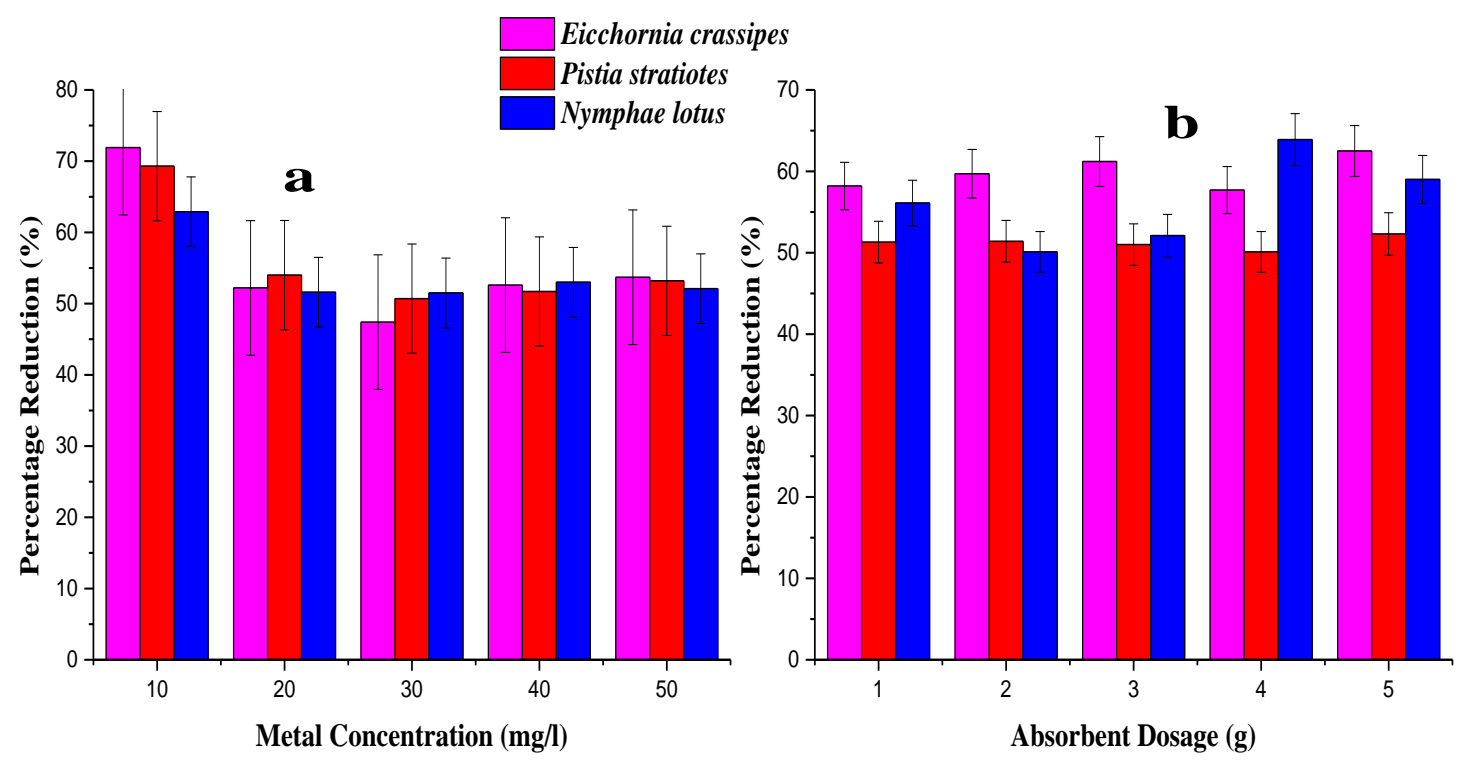

Figure 3. Effect of absorbent dosage (a), metal concentration (b) on Ni biosorption

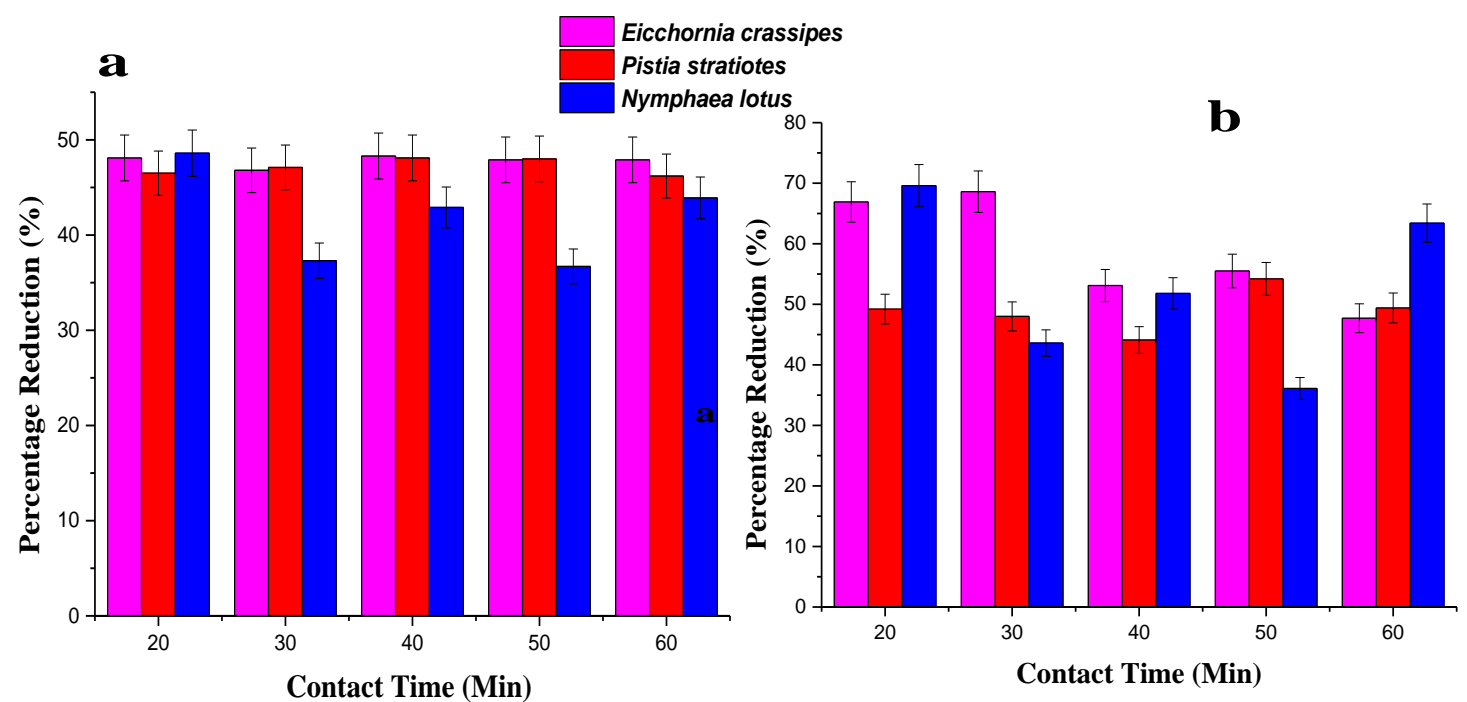

Figure 4. Effect of contact time and particle size (a) small size (b) large size on the absorption of $\mathrm{Ni}$ 


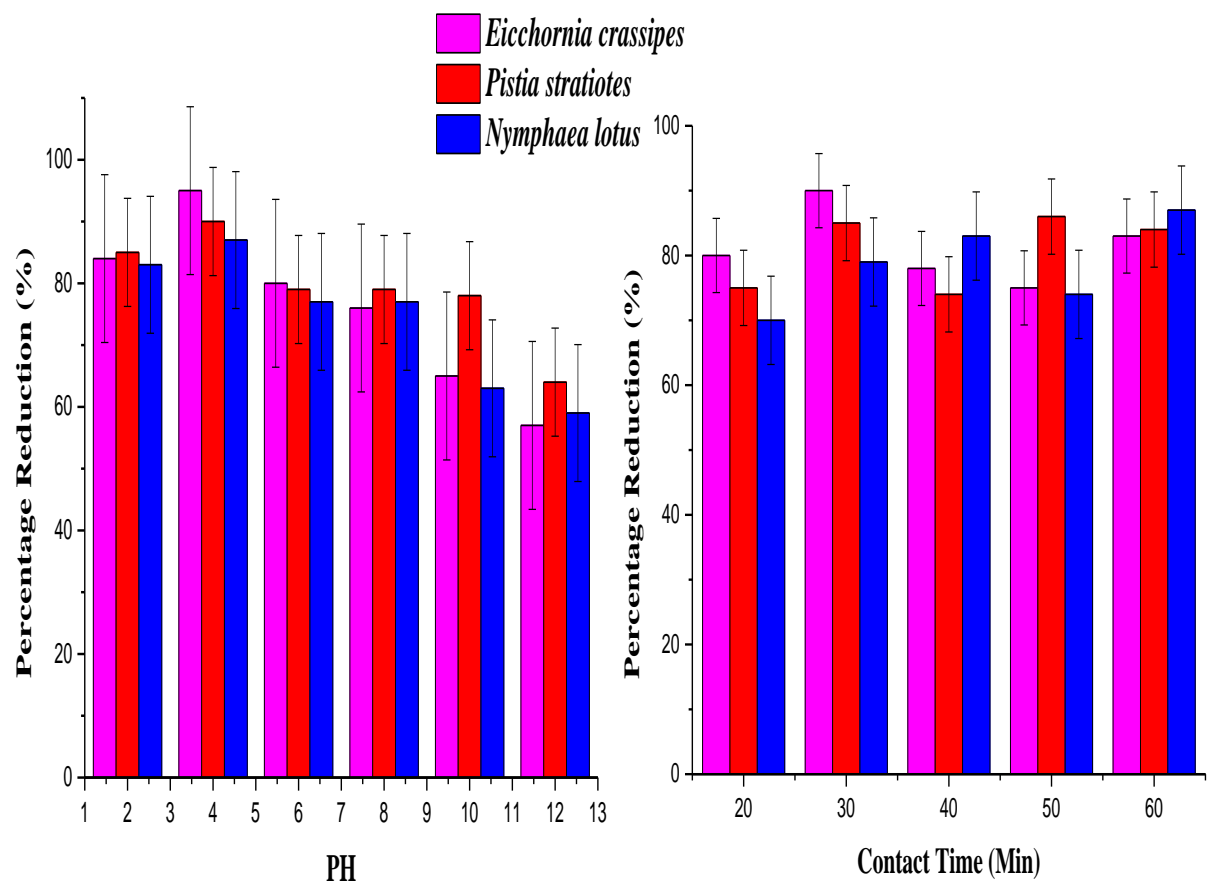

Figure 5. (a) Effect of PH on Ni absorption from aqueous solution. (b) Effect of contact time on the Ni absorption from refinery wastewater

\section{Adsorption isotherms}

The Langmuir model obtained gives a nearly perfect fitting for adsorption of $\mathrm{Ni}^{2+}$ for Eichhornia crassipes (0.9933) and Pistia stratiotes (0.9898) while poor-fitting was recorded for Nymphaea lotus (0.9311). Although it can be concluded that the adsorption of $\mathrm{Ni}^{2+}$ onto Eichhornia crassipes, Pistia stratiotes, and Nymphaea lotus correlated well with Langmuir equation with the relationship becoming more linear with $\mathrm{R}^{2}$ value closer to 1 (Amer et al., 2015; Ugya et al., 2019c). The Freundlich model shows a nearly perfect fitting for absorption of $\mathrm{Ni}^{2+}$ for Eichhornia crassipes (0.9978), Pistia stratiotes (0.9885) and Nymphaea lotus (0.9753) with a high $\mathrm{n}$ value of (3.1) Eichhornia crassipes, (2.7) Pistia stratiotes and (2.3) Nymphaea lotus which are all within the range of 1-10 signifying favourable absorption of $\mathrm{Ni}^{2+}$ for Eichhornia crassipes, Pistia stratiotes and Nymphaea lotus (Rosales et al., 2016; Poonam et al., 2018).

\section{Adsorption kinetics}

The biosorption of $\mathrm{Ni}^{2+}$ by Eichhornia crassipes, Pistia stratiotes, and Nymphaea lotus was determined at various initial concentration and time interval for the understanding of biosorption mechanism (Manikandan et al., 2016). The result obtained shows that the Pseudo Second-order kinetic model gives nearly perfect fitting for Eichhornia crassipes (0.9194) and Pistia stratiotes (0.9645) but poor fitting for Nymphaea lotus (0.7329). The correlation coefficient shows that the absorption of $\mathrm{Ni}$ by Eichhornia crassipes, Pistia stratiotes, and Nymphaea lotus follows the pseudo secondorder kinetic model because poor fittings of (0.7501) Eichhornia crassipes, (0.5678) Pistia stratiotes and (0.5404) Nymphaea lotus was obtained for pseudo-first order model. This result obtained signifies that that the absorption of $\mathrm{Ni}^{2+}$ to Eichhornia crassipes, Pistia stratiotes and Nymphaea lotus is due to chemical and physical reaction 
of $\mathrm{Ni}^{2+}$ and the surface of Eichhornia crassipes, Pistia stratiotes and Nymphaea lotus which leads to the formation of bond between the valence electron and the negative surface charge of Eichhornia crassipes, Pistia stratiotes and Nymphaea lotus to attain an equilibrium state (Low et al., 1994).

\section{Conclusion}

The petrochemical refining industry is the world largest contributor of $\mathrm{Ni}^{2+}$ particularly in developing countries like Nigeria where wastewater containing $\mathrm{Ni}^{2+}$ is discharged into nearby water bodies without proper treatment due to low technologic know-how. It is thereby paramount for petrochemical refineries to utilize the availability of aquatic macrophytes as low-cost absorbents for further treatment of its wastewater before discharge since most industries are unwilling to establish a costly convectional treatment plant.

The comparison of the present study and other research as shown in Table 3, shows that although Eicchornia crassipes have the highest $\mathrm{Ni}^{2+}$ reduction efficiency both Pistia stratiotes and Nymphaea lotus can also be used effectively as biosorbents for the removal of $\mathrm{Ni}^{2+}$ from refinery wastewater.

Table 3. Comparison of biosorption efficiency of $\mathrm{Ni}^{2+}$ by different macrophytes

\begin{tabular}{c|c|c|c|c}
\hline SN & Macrophytes & Heavy metal & Percentage reduction (\%) & References \\
\hline 1 & Eichhornia crassipes & $N i^{2+}$ & 90 & Present study \\
2 & Pistia stratiotes & $N i^{2+}$ & 87 & Present study \\
3 & Nymphaea lotus & $N i^{2+}$ & 86 & Present study \\
4 & Lemna minor & $N i^{2+}$ & 82 & Axtell et al. (2003) \\
5 & Hydrilla verticillata & $N i^{2+}$ & 92 & Mishra et al. (2016) \\
6 & Salvinia $s p$ & $N i^{2+}$ & 71.4 & Dhir and Kumar (2010) \\
\hline
\end{tabular}

Further investigation is needed on how to increase the efficiency of these macrophytes for the uptake of $\mathrm{Ni}^{2+}$. More research needs to be done using more macrophytes such as Salvinia sp, Azolla sp, Ludwigia sp, etc to discover more novel eco-friendly cheap biosorbent for $\mathrm{Ni}^{2+}$ removal from wastewater.

Acknowledgments. The first author appreciates Petroleum Technology Development Fund (PTDF) Nigeria for providing the fund and enabling environment to carry out the research.

\section{REFERENCES}

[1] Abdic, S., Memic, M., Sabanovic, E., Sulejmanovic, J., Begic, S. (2018): Adsorptive removal of eight heavy metals from aqueous solution by unmodified and modified agricultural waste: tangerine peel. - International Journal of Environmental Science and Technology 15: 2511-2518.

[2] Amer, M. W., Ahmad, R. A., Awwad, A. M. (2015): Biosorption of Cu(II), Ni(II), Zn(II) and $\mathrm{Pb}$ (II) ions from aqueous solution by Sophora japonica pods powder. - International Journal of Industrial Chemistry 6: 67-75. 
[3] Axtell, N. R., Sternberg, S. P. K., Claussen, K. (2003): Lead and nickel removal using Microspora and Lemna minor. - Bioresource Technology 89: 41-48.

[4] Bordoloi, S., Yamsani, S. K., Garg, A., Sreedeep, S., Borah, S. (2015): Study on the efficacy of harmful weed species Eicchornia crassipes for soil reinforcement. Ecological Engineering 85: 218-222.

[5] Chen, H.-G., Peng, F., Zhang, Z.-Y., Zhang, L., Zhou, X.-D., Liu, H.-Q., Wang, W., Liu, G.-F., Xue, W.-D., Yan, S.-H., Xu, X.-F. (2012): Effects of engineered use of water hyacinths (Eicchornia crassipes) on the zooplankton community in Lake Taihu, China. Ecological Engineering 38: 125-129.

[6] Costa-Boeddeker, S., Le Xuan, T., Hoelzmann, P., de Stigter, H. C., van Gaever, P., Hoang Duc, H., Schwalb, A. (2018): The hidden threat of heavy metal pollution in high sedimentation and highly dynamic environment: assessment of metal accumulation rates in the Thi Vai Estuary, Southern Vietnam. - Environmental Pollution 242: 348-356.

[7] Desrosiers, M., Usseglio-Polatera, P., Archaimbault, V., Larras, F., Methot, G., PinelAlloul, B. (2019): Assessing anthropogenic pressure in the St. Lawrence River using traits of benthic macroinvertebrates. - Science of the Total Environment 649: 233-246.

[8] Dhir, B., Kumar, R. (2010): Adsorption of heavy metals by Salvinia biomass and agricultural residues. - International Journal of Environmental Research 4: 427-432.

[9] Dudgeon, D., Arthington, A. H., Gessner, M. O., Kawabata, Z.-I., Knowler, D. J., Leveque, C., Naiman, R. J., Prieur-Richard, A.-H., Soto, D., Stiassny, M. L. J., Sullivan, C. A. (2006): Freshwater biodiversity: importance, threats, status and conservation challenges. - Biological Reviews 81: 163-182.

[10] Feng, N., Guo, X., Liang, S., Zhu, Y., Liu, J. (2011): Biosorption of heavy metals from aqueous solutions by chemically modified orange peel. - Journal of Hazardous Materials 185: 49-54.

[11] Galal, T. M., Farahat, E. A. (2015): The invasive macrophyte Pistia stratiotes, L. as a bioindicator for water pollution in Lake Mariut, Egypt. - Environmental Monitoring and Assessment 187. https://doi.org/10.1007/s10661-015-4941-4.

[12] Gusain, R., Suthar, S. (2017): Potential of aquatic weeds (Lemna gibba, Lemma minor, Pistia stratiotes and Eichhornia sp.) in biofuel production. - Process Safety and Environmental Protection 109: 233-241.

[13] Hanafiah, M. M., Mohamad, N. H. S. M., Abd Aziz, N. I. H. (2018): Salvinia molesta and Pistia stratiotes as phytoremediation agents in sewage wastewater treatment. - Sains Malaysiana 47: 1625-1634.

[14] Hanks, N. A., Caruso, J. A., Zhang, P. (2015): Assessing Pistia stratiotes for phytoremediation of silver nanoparticles and $\operatorname{Ag}(\mathrm{I})$ contaminated waters. - Journal of Environmental Management 164: 41-45.

[15] He, J., Chen, J. P. (2014): A comprehensive review on biosorption of heavy metals by algal biomass: Materials, performances, chemistry, and modeling simulation tools. Bioresource Technology 160: 67-78.

[16] Ho, Y. S., McKay, G. (1998): A comparison of chemisorption kinetic models applied to pollutant removal on various sorbents. - Process Safety and Environmental Protection 76: 332-340.

[17] Hughes, D. J., Shimmield, T. M., Black, K. D., Howe, J. A. (2015): Ecological impacts of large-scale disposal of mining waste in the deep sea. - Scientific Reports 5: \#9985.

[18] Ileri, O., Cay, S., Uyanik, A., Erdura, N. (2014): Removal of common heavy metals from aqueous solutions by waste Salvadora persica L. branches (Miswak). - International Journal of Environmental Research 8: 987-996.

[19] Kumar, K., Patavardhan, S. S., Lobo, S., Gonsalves, R. (2018): Equilibrium study of dried orange peel for its efficiency in removal of cupric ions from water. - International Journal of Phytoremediation 20: 593-598. 
[20] Lamb, J. B., Wenger, A. S., Devlin, M. J., Ceccarelli, D. M., Williamson, D. H., Willis, B. L. (2016): Reserves as tools for alleviating impacts of marine disease. - Philos Trans R Soc Lond B Biol Sci 371. https://doi.org/10.1098/rstb.2015.0210.

[21] Lareo, L. (1981): Growth of the water hyacinth (Eichhornia crassipes (Mart) Solms Laubach) in the tropics. - Archivos Latinoamericanos de Nutricion 31: 758-765.

[22] Lintern, A., Leahy, P. J., Heijnis, H., Zawadzki, A., Gadd, P., Jacobsen, G., Deletic, A., McCarthy, D. T. (2016): Identifying heavy metal levels in historical flood water deposits using sediment cores. - Water Research 105: 34-46.

[23] Liu, M., Du, P., Yu, C., He, Y., Zhang, H., Sun, X., Lin, H., Luo, Y., Xie, H., Guo, J., Tong, Y., Zhang, Q., Chen, L., Zhang, W., Li, X., Wang, X. (2018): Increases of total mercury and methylmercury releases from municipal sewage into environment in China and implications. - Environmental Science \& Technology 52: 124-134.

[24] Low, K. S., Lee, C. K., Tai, C. H. (1994): Biosorption of copper by water hyacinth roots. - Journal of Environmental Science and Health. Part A: Environmental Science and Engineering and Toxicology 29: 171-188.

[25] Ma, J., Ugya, Y. A., Isiyaku, A. U., Hua, X., Imam, T. S. (2019): Evaluation of Pistia stratiotes fractions as effective larvicide against Anopheles mosquitoes. - Artificial Cells, Nanomedicine, and Biotechnology 47: 945-950.

[26] Manikandan, N. A., Alemu, A. K., Goswami, L., Pakshirajan, K., Pugazhenthi, G. (2016): Waste litchi peels for $\mathrm{Cr}(\mathrm{VI})$ removal from synthetic wastewater in batch and continuous systems: sorbent characterization, regeneration and reuse study. - Journal of Environmental Engineering 142(9).

[27] Migahed, F., Abdelrazak, A., Fawzy, G. (2017): Batch and continuous removal of heavy metals from industrial effluents using microbial consortia. - International Journal of Environmental Science and Technology 14: 1169-1180.

[28] Mishra, A., Tripathi, B. D., Rai, A. K. (2016): Packed-bed column biosorption of chromium(VI) and nickel(II) onto Fenton modified Hydrilla verticillata dried biomass. Ecotoxicology and Environmental Safety 132: 420-428.

[29] Nahar, K., Chowdhury, M. A. K., Chowdhury, M. A. H., Rahman, A., Mohiuddin, K. M. (2018): Heavy metals in handloom-dyeing effluents and their biosorption by agricultural byproducts. - Environmental Science and Pollution Research 25: 7954-7967.

[30] Nor, Y. M. (1994): Phenol removal by Eichhornia crassipes in the presence of trace metals. - Water Research 28: 1161-1166.

[31] Osti, J. A. S., Henares, M. N. P., Camargo, A. F. M. (2018): The efficiency of freefloating and emergent aquatic macrophytes in constructed wetlands for the treatment of a fishpond effluent. - Aquaculture Research 49: 3468-3476.

[32] Poonam, S., Bharti, K., Kumar, N. (2018): Kinetic study of lead $\left(\mathrm{Pb}^{2+}\right)$ removal from battery manufacturing wastewater using bagasse biochar as biosorbent. - Applied Water Science 8: 119. https://doi.org/10.1007/s13201-018-0765-z.

[33] Pulzatto, M. M., Lolis, L. A., Louback-Franco, N., Mormul, R. P. (2018): Herbivory on freshwater macrophytes from the perspective of biological invasions: a systematic review. - Aquatic Ecology 52: 297-309.

[34] Rosales, E., Meijide, I., Tavares, T., Pazos, M., Sanroman, M. A. (2016): Grapefruit peelings as a promising biosorbent for the removal of leather dyes and hexavalent chromium. - Process Safety and Environmental Protection 101: 61-71.

[35] Salim, R. M., Chowdhury, A. J. K., Rayathulhan, R., Yunus, K., Sarkar, M. Z. I. (2016): Biosorption of $\mathrm{Pb}$ and $\mathrm{Cu}$ from aqueous solution using banana peel powder. Desalination and Water Treatment 57: 303-314.

[36] Sujatha, P., Kalarani, V., Kumar, B. N. (2013): Effective biosorption of nickel(II) from aqueous solutions using Trichoderma viride. - Journal of Chemistry 2013: 7.

[37] Tchounwou, P. B., Yedjou, C. G., Patlolla, A. K., Sutton, D. J. (2012): Heavy metal toxicity and the environment. - Experientia Supplementum 101: 133-164. 
[38] Tong, T., Elimelech, M. (2016): The global rise of zero liquid discharge for wastewater management: drivers, technologies, and future directions. - Environmental Science \& Technology 50: 6846-6855.

[39] Ugya, A. Y. (2015): The efficiency of Lemna minor L. in the phytoremediation of Romi Stream: a case study of Kaduna Refinery and Petrochemical Company polluted stream. Journal of Applied Biology and Biotechnology 3: 11-14.

[40] Ugya, A. Y., Imam, T. S. (2017): Temporal heavy metals variation in vegetables sampled at Kasuwan Mata, Kaduna Metropolis, Nigeria. - Malaysia Journal of Sciences 36: 63-74.

[41] Ugya, A. Y., Imam, T. S., Tahir, S. M. (2015): The efficiency of Pistia stratiotes in the phytoremediation of Romi Stream. - International Journal of Health and Research 5: 492497.

[42] Ugya, A.Y., Imam, T.S., Ma, J. (2019a) Mini-review on the Efficacy of the use of Macrophytes as Larvicide against Mosquitoes. - Journal of Applied Botany and Food Quality. Accepted Article.

[43] Ugya, A. Y., Ahmad, A. M., Adamu, I. H., Giwa, S. M., Imam, T. S. (2019b): Phytoextraction of heavy metals and risk associated with vegetables grown from soil irrigated with refinery wastewater. - Journal of Applied Biology and Biotechnology 7: 14-19.

[44] Ugya, A. Y., Hua, X., Agamuthu, P., Ma, J. (2019c): Molecular approach to uncover the function of bacteria in petrochemical refining wastewater: a mini review. - Applied Ecology and Environmental Research 17: 3645-3665.

[45] Ugya, A. Y., Hua, X., Ma, J. (2019d): Biosorption of $\mathrm{Cr}^{3+}$ and $\mathrm{Pb}^{2+}$ from tannery wastewater using combined fruit waste. - Applied Ecology and Environmental Research 17: 1773-1787.

[46] Ugya, A. Y., Hua, X., Ma, J. (2019e): Phytoremediation as a tool for the remediation of wastewater resulting from dyeing activities. - Applied Ecology and Environmental Research 17: 3723-3735.

[47] Wang, S., Yang, S., Jin, X., Liu, L., Wu, F. (2010): Use of low cost crop biological wastes for the removal of Nitrobenzene from water. - Desalination 264: 32-36.

[48] Wang, X., Meng, X., Ma, Y., Pu, X., Zhong, X. (2018): The prediction of combined toxicity of $\mathrm{Cu}-\mathrm{Ni}$ for barley using an extended concentration addition model. Environmental Pollution 242: 136-142.

[49] Xun, E., Zhang, Y., Zhao, J., Guo, J. (2018): Heavy metals in nectar modify behaviors of pollinators and nectar robbers: consequences for plant fitness. - Environmental Pollution 242: 1166-1175.

[50] Zhang, C., Anadon, L. D. (2013): Life cycle water use of energy production and its environmental impacts in China. - Environmental Science \& Technology 47: 1445914467. 